\title{
STRATEGI PEMASARAN MOTOR HONDA PADA PT. BINTANG MOTOR BENGKULU
}

\author{
Andriyani Prawitasari, Englin Roziz \\ Program Studi Manajemen, Fakultas Ekonomi Universitas Dehasen Bengkulu \\ andriyaniprawitasari@gmail.com
}

\begin{abstract}
ABSTRAK
Andriyani Prawitasari, Englin Roziz; Tujuan penelitian ini adalah untuk mengetahui strategi pemasaran PT. Bintang Motor Bengkulu. Metode analisis yang digunakan adalah analisis SWOT yang terdiri dari Matrik Faktor Strategi Internal (IFAS) dan Matrik Faktor Strategi Eksternal (EFAS).

Hasil analisis SWOT didapat dari nilai kekuatan yang dimiliki adalah 25,71 sedangkan kelemahan adalah 13,26 jadi kuadran internal faktor yaitu 25,71-13,26 =12,45 artinya kemampuan dari PT. Bintang Motor Bengkulu dalam memanfaatkan kekuatan dan meminimalkan kelemahan yang terdapat pada internal perusahaan. Peluang yang dimiliki dari strategi tersebut sebesar 19,30 dan ancaman sebesar 12,52. Jadi kuadran eksternal faktor yaitu 19,30 - 12,52=6,78 artinya kemampuan yang tinggi dari PT. Bintang Motor Bengkulu dalam memanfaatkan peluang-peluang dan mengatasi ancaman-ancaman yang dihadapi oleh perusahaan dalam penjualan. Sehingga berada pada kuadran I yaitu strategi agresif dengan cara menerapkan: 1) Menjaga kualitas dan mutu produk-produk honda serta melakukan pelayanan yang dapat meyakini dan memuaskan konsumen. 2) Memanfaatkan kekuatan dalam memasarkan produk berdasarkan kualitas dan mutu melalui promosi, sponsorship dan pameran sehingga PT. Bintang Motor semakin diyakini dan dikenal masyarakat.
\end{abstract}

\section{ABSTRACT}

Andriyani Prawitasari, Englin Roziz; This study aims to determine the marketing strategy of PT. Bintang Motor Bengkulu. The analysis method was used SWOT analysis consist of Internal Strategy Factor Matrix (IFAS) and External Strategy Factor (EFAS).SWOT analysis results obtained from the strength value is 25.71 while the weakness is 13.26 so the internal quadrant factor is 25.71-13.26 =12.45, it means the ability of PT. Bintang Motor Bengkulu in harnessing the strength and minimize the weaknesses that are in the internal company. Opportunities of the strategy is 19.30 and the threat of 12.52. So the external quadrant factor is 19.30 - $12.52=6.78$ means the high ability of of PT. Bintang Motor Bengkulu in exploiting the opportunities and overcome the threats faced by the company in the sale. So that is in the first quadrant is an aggressive strategy by applying: 1) Maintaining the quality and quality of honda products and perform services that can believe and satisfy consumers. 2) Harness the power in marketing the product based on quality and quality through promotion, sponsorship and exhibition so that of PT. Bintang Motor Bengkuluare increasingly believed and known to the public.

Key Words: Marketing Strategy, SWOT

\section{LATAR BELAKANG}

Berkembangnya teknologi persaingan dalam bidang industri penjualan saat ini semakin ketat, dimana kondisi ini memungkinkan perusahaan gagal dalam mencapai laba yang maksimal, dan kemungkinan yang lebih buruk lagi perusahaan akan merugi. Dengan persaingan yang sangat ketat ini mengharuskan perusahaan terus bertahan dan mampu menghasilkan laba. Sesuai dengan tujuan utama suatu perusahaan yaitu mencari atau mencapai laba yang maksimal. Laba yang maksimal dapat diperoleh melalui peningkatan volume penjualan. Semakin tinggi volume penjualan, maka semakin besar pula laba yang akan diperoleh karena penjualan merupakan unsur utama dalam memperbesar laba.

Setiap perusahaan, baik yang bergerak di bidang produk ataupun jasa, mempunyai tujuan untuk tetap hidup dan berkembang, tujuan tersebut dapat dicapai melalui upaya untuk dapat mempertahankan dan meningkatkan tingkat keuntungan atau laba operasional perusahaan. Hal ini dapat dilakukan, jika perusahaan dapat mempertahankan dan meningkatkan penjualan produk atau jasa yang mereka produksi. Dengan melakukan penerapan strategi pemasaran yang akurat melalui pemanfaatan peluang dalam meningkatkan penjualan, sehingga posisi atau kedudukan perusahaan di pasar dapat ditingkatkan atau dipertahankan. Sehubungan dengan hal tersebut pelaksanaan pemasaran modern saat ini mempunyai peranan yang sangat besar sebagai penunjang langsung terhadap peningkatan laba perusahaan. 
Ada banyak hal atau cara yang dilakukan oleh pihak manajemen untuk meningkatkan volume penjualan. Cara yang mereka gunakan atau lakukan mulai dari potongan harga penjualan (cash back), pemberian hadiah dalam pembelian produk, sampai dengan penjualan secara kredit untuk mempermudah konsumen. Penjualan kredit memang tidak langsung menghasilkan penerimaan kas, tetapi menghasilkan piutang terhadap konsumen atau disebut piutang usaha. Pada saat jatuh tempo kemudian aliran kas masuk ( cash in flow) yang berasal dari piutang usaha tersebut. Sebuah perusahaan hendaklah menciptakan strategi pemasaran yang baik untuk terus meningkatkan volume penjualan perusahaannya.

Menurut Purwanto (2011: 77) strategi berasal dari bahasa Yunani yaitu strategos yang dengan kata jamak strategi. Strategi yang berarti seni atau ilmu untuk menjadi seorang Jenderal. Konsep strategi militer seringkali digunakan dan diterapkan dalam dunia bisnis yang mengikuti lingkungan yang dipilih dan merupakan pedoman untuk mengalokasikan sumber daya dan usaha suatu perusahaan.

Menurut Kotler (2012: 10) pemasaran adalah proses sosial yang dengan mana individu dan kelompok mendapatkan apa yang mereka butuhkan dan inginkan dengan menciptakan, menawarkan, dan secara bebas mempertukarkan produk dan jasa yang bernilai dengan pihak lain.

Jadi strategi pemasaran adalah suatu wujud rencana yang terurai dibidang pemasaran. Untuk memperoleh hasil yang optimal, strategi pemasaran ini mempunyai ruang lingkup yang luas di bidang pemasaran diantaranya adalah strategi dalam menghadapi persaingan, strategi harga, strategi produk, strategi pelayanan dan sebagainya. Perusahaan perlu mengenali kekuatan dan kelemahan perusahaan dalam persaingan hal ini akan sangat membantu dalam mengenali diri, serta memanfaatkan setiap peluang yang ada dan menghindari atau meminimalkan. Dimana strategi pemasaran merupakan upaya mencari posisi pemasaran yang menguntungkan dalam suatu industri atau arena fundamental persaingan berlangsung.

Setiap perusahaan mengarahkan kegiatan usahanya untuk dapat menghasilkan produk yang dapat memberikan kepuasan kepada konsumen sehingga dalam jangka waktu dan jumlah produk tertentu dapat diperoleh keuntungan seperti yang diharapkan. Melalui produk yang dihasilkannya, perusahaan menciptakan, membina dan mempertahankan kepercayaan langganan akan produk tersebut. Keberhasilan suatu perusahaan sangat ditentukan oleh ketepatan produsen dalam memberikan kepuasan kepada sasaran konsumen yang ditentukannya, dimana usaha-usaha pemasaran diarahkan kepada konsumen yang ditujukan sebagai sasaran pasarnya.

Di Bengkulu saat ini banyak berdiri berbagai macam dealer sepeda motor, yang memiliki berbagai produk baru dan inovasi-inovasi baru serta promosi yang cukup cepat melalui berbagai hal untuk memperkenalkan produk-produk barunya kepada konsumen, dari jenis produk, mutu produk, harga produk dan kemudahan-kemudahan yang ditawarkan oleh dealer. Salah satu dealer motor di kota Bengkulu yang melakukan kegiatan penjualan sepeda motor merek Honda. Strategi pemasaran yang dilakukan dealer Bintang Motor Bengkulu diantaranya dengan promosi dan iklan untuk meningkatkan volume penjualan motor Honda.

Salah satu penawaran yang banyak menarik minat masyarakat pada PT. Bintang Motor Bengkulu adalah adanya penawaran khusus setiap bulan dan tahunnya. Penawaran khusus setiap bulan, berupa pemberian hadiah langsung untuk pembelian unit sepeda motor Honda. Sedangkan penawaran khusus setiap tahun, berupa kupon undian untuk pembelian unit sepeda motor Honda yang akan diundi setiap akhir tahun.

Berdasarkan kondisi persaingan yang ketat diharapkan sebuah perusahaan harus menggunakan strategi dalam pemasaran untuk terus meningkatkan volume penjualan. Dengan demikian, perlu diadakannya penelitian, untuk mengetahui faktor-faktor yang mempengaruhi tingkat penjualan.

\section{LANDASAN TEORI} Strategi Pemasaran

Menurut Prahalad dalam Durianto (2011:31) strategi didefinisikan secara khusus sebagai tindakan yang bersifat incremental (senantiasa meningkat) dan terus-menerus, serta dilakukan berdasarkan sudut pandang tentang apa yang diharapkan oleh para pelanggan di masa depan. Dalam konsep pemasaran menurut Kotler (2012:10) pemasaran adalah proses sosial yang dengan mana individu dan kelompok mendapatkan apa yang mereka butuhkan dan inginkan dengan menciptakan, menawarkan, dan secara bebas mempertukarkan produk dan jasa yang bernilai dengan pihak lain. Menurut Kotler dalam Purwanto (2011:151) dalam mendesain suatu strategi pemasaran, hal terpenting yang dilakukan oleh manajemen pemasaran adalah penerapan konsep STP (Segmentation, Targeting, Positioning) konsep ini saling terkait satu sama lainnnya, secara garis besar langkah-langkah STP sebagai berikut : 
1. Segmentasi pasar yaitu mengidentifikasi variabel segmentasi pasar dan mengembangkan gambaran segmen yang dihasilkan.

2. Target pasar yaitu mengevaluasi daya tarik masing-masing segmen dan memilih segmen-segmen pasar.

3. Posisi pasar yaitu mengidentifikasikan konsep posisi pasar yang memungkinkan bagi masing-masing segmen pasar dan memilih, mengembangkan dan mengkomunikasikan konsep posisi pasar yang dipilih.

Segmentasi pasar digunakan untuk mendesain produk-produk yang lebih reponsive terhadap kebutuhan pasar. Dalam strategi pemasaran pada dasarnya rencana yang menyeluruh, terpadu dan menyatu di bidang pemasaran yang memberikan panduan tentang kegiatan yang akan dijalankan untuk mencapai tujuan pemasaran suatu perusahaan. Terdapat beberapa jenis-jenis strategi pemasaran menurut Assauri (2013:179) bahwa strategi pemasaran secara umum ini, dapat dibedakan tiga jenis strategi pemasaran yang dapat ditempuh perusahaan yaitu:

1. Strategi pemasaran yang tidak membeda-bedakan pasar (Undifferentiated marketing).

2. Strategi pemasaran yang membeda-bedakan pasar (Differentiated marketing).

3. Strategi pemasaran yang terkonsentrasi (Concentrated Marketing).

\section{Analisis SWOT}

Analisis SWOT menurut Sutojo dan Kleinsteuber (2010: 8) adalah untuk menentukan tujuan usaha yang realistis sesuai dengan kondisi perusahaan dan oleh karenanya diharapkan lebih mudah tercapai. SWOT adalah singkatan dari kata-kata Strength (kekuatan perusahaan) Weaknesses (kelemahan perusahaan), Opportunities (peluang bisnis) dan Threats (hambatan untuk mencapai tujuan). Penjelasan secara terinci SWOT sebagai berikut:

a. Strength (kekuatan)

Adalah suatu keunggulan sumber daya yang belum tergali dengan optimal sehingga memberikan kemungkinan organisasi untuk lebih meningkatkan kinerjanya. Kekuatan merupakan sumber daya, keunggulan relatif terhadap pesaing dan kebutuhan pasar yang ingin dilayani oleh organisasi, kekuatan adalah kompetisi khusus yang memberikan keunggulan komparatif dari pasar.

b. Weakness (kelemahan)

Adalah keterbatasan dan kekurangan sumber daya, keterampilan yang dibutuhkan organisasi sehingga menghambat kinerja efektif dari organisasi dalam pengembangan usahanya.

c. Opportunities (peluang)

Adalah unsur-unsur lingkungan luar (politik, ekonomi, sosial dan IPTEK) positif yang memberikan kesempatan dan mendukung keberadaan organisasi. Peluang merupakan situasi penting yang menguntungkan. Identifikasi segmen pasar yang terabaikan, perubahan teknologi serta membaiknya hubungan dengan investor dapat memberikan peluang untuk pengembangan usaha.

d. Threats (ancaman)

Adalah unsur-unsur lingkungan luar (politik, ekonomi, sosial dan IPTEK) negatif yang menghambat kegiatan pelayanan transportasi. Ancaman merupakan situasi yang paling tidak menguntungkan dan merupakan pengganggu utama dalam pengembangan pelayanan, masuknya pesaing baru dan lambatnya kegiatan pelayanan merupakan ancaman bagi peningkatan kualitas pelayanan.

\section{METODE PENELITIAN}

Jenis penelitian ini adalah deskriptif kualitatif. Menurut Mulyono (2014:42) yaitu penelitian yang bertujuan untuk apa yang saat ini berlaku, dan di dalamnya terdapat upaya mendeskripsikan, mencatat, analisis, dan menginterprestasikan kondisi-kondisi yang sekarang ini terjadi. Dengan kata lain penelitian deskriptif bertujuan untuk memperoleh informasi-informasi mengenai keadaan saat ini dan melihat kaitan antara variabel-variabel yang ada.

Populasi dalam penelitian ini yaitu seluruh marketing 15 orang, Kepala Cabang 1 orang dan konsumen dari PT. Bintang Motor Kota Bengkulu 1.800 orang (dalam satu tahun terakhir pada tahun 2017). Sampel dalam penelitian sebanyak 79 orang yang terdiri 4 orang untuk faktor internal yaitu : 1 orang Kepala Cabang Bapak Widi Setiawan, dan 3 orang bagian pemasaran Bapak David Agung Kurniadi, Ibu Wulan dan Bapak Asep Bandung dari PT. Bintang Motor Bengkulu dan 75 orang untuk faktor eksternal yaitu konsumen pada PT. Bintang Motor Bengkulu. Metode pengumpulan data dalam penelitian ini adalah kuesioner yaitu teknik pengumpulan data yang dilakukan dengan cara memberi seperangkat pertanyaan atau pernyataan tertulis kepada responden untuk dijawabnya (Sugiyono, 2013:142).

Data yang diperoleh dalam penelitian ini didapatkan langsung dari pengisian kuesioner (angket) yang ditujukan kepada responden. Pertanyaan atau pernyataan pada angket tertutup di ukur dengan 
skala likert dengan skor 1-5. Skor 1-5 digunakan peneliti karena lebih sederhana dan memiliki nilai tengah yang digunakan untuk menjelaskan keraguan-keraguan atau netral dalam memilih jawaban. Oleh karena itu skala likert ini lazim digunakan di Indonesia untuk yang mengukur sikap, pendapat, dan persepsi seseorang. Untuk analisis kuantitatif, maka jawaban itu dapat diberi skor yang ditunjukkan pada tabel berikut:

Tabel 1. Skala Likert

\begin{tabular}{|l|c|}
\hline \multicolumn{1}{|c|}{ Pilihan Jawaban } & Skor \\
\hline Sangat Tidak Setuju & 1 \\
\hline Tidak Setuju & 2 \\
\hline Netral & 3 \\
\hline Setuju & 4 \\
\hline Sangat Setuju & 5 \\
\hline
\end{tabular}

Sumber : Sugiyono (2013: 93)

Metode analisis yang digunakan dalam penelitian ini adalah analisis SWOT, untuk mengetahui kekuatan (strenght), kelemahan (weakness), peluang (oppurtunity), dan ancaman (thereats) pada PT. Bintang Motor Bengkulu.

Menurut Fahmi (2011 : 223) untuk menghitung nilai bobot, rating dan skor untuk tabel faktorfaktor strategi internal dan faktor-faktor strategi eksetrnal dengan teknik skala sebagai berikut:

1. Bobot

$\begin{array}{ll}\text { Sangat Setuju (SS) } & =1,00 \\ \text { Setuju (S) } & =0,75 \\ \text { Netral (N) } & =0,50 \\ \text { Tidak Setuju (TS) } & =0,25 \\ \text { Sangat Tidak Setuju (STS) } & =0,10\end{array}$

2. Rating

$5 \quad=$ Sangat Baik

$4 \quad=$ Baik

$3=$ Netral

$2 \quad=$ Tidak Baik

1 = Sangat Tidak Baik

3. Untuk menghitung nilai skor menggunakan formulasi sebagai berikut:

$$
\text { Bobot relatif }=\frac{\frac{\text { Fumlah Iawaban } x \text { Dobot }}{\text { Iumlah Responden }}}{\text { tuml }}
$$$$
\text { Skor = Bobot Relatif } \mathrm{x} \text { Rating }
$$

Menurut Rangkuti (2015 : 20) analisis data yang digunakan untuk memecahkan masalah dengan SWOT adalah dengan langkah-langkah sebagai berikut:

a. Matrik SWOT

b. Analisis SWOT merupakan alat analisis yang menggambarkan bagaiman manajemen perusahaan dapat menyusun alternatif strategi dengan mencocokan peluang-peluang dan ancaman-ancaman eksternal yang dihadapi dengan kekuatan dan kelemahan yang dimiliki perusahaan. Dalam analisis SWOT terdapat empat alternatif strategi, yaitu strategi yang mencocokan kekuatan dengan peluang (SO), kekuatan dengan ancaman (ST), kelemahan dengan peluang (WO) serta kelemahan dengan ancaman (WT).

Adapun gambaran dari matrik SWOT tersebut adalah sebagai berikut: 
Tabel 2. Matrik SWOT

\begin{tabular}{|c|c|c|}
\hline 7 & $\begin{array}{c}\text { Strengths }(S) \\
\text { Menentukan Faktor-Faktor Kekuatan } \\
\text { Internal }\end{array}$ & $\begin{array}{c}\text { Weaknesses }(W) \\
\text { Menentukan Faktor-Faktor } \\
\text { Kelemahan Internal }\end{array}$ \\
\hline $\begin{array}{c}\text { Opportunities }(\mathrm{O}) \\
\text { Menentukan Faktor-Faktor } \\
\text { Peluang Eksternal }\end{array}$ & $\begin{array}{c}\text { Strategi SO } \\
\text { Ciptakan strategi yang menggunakan } \\
\text { kekuatan untuk memanfaatkan } \\
\text { peluang }\end{array}$ & $\begin{array}{c}\text { Strategi WO } \\
\text { Ciptakan strategi yang } \\
\text { meminimalkan kelemahan } \\
\text { untuk memanfaatkan peluang }\end{array}$ \\
\hline $\begin{array}{c}\text { Threats }(T) \\
\text { Menentukan Faktor-Faktor } \\
\text { Ancaman Eksternal }\end{array}$ & $\begin{array}{c}\text { Strategi ST } \\
\text { Ciptakan strategi yang menggunakan } \\
\text { kekuatan untuk mengatasi ancaman }\end{array}$ & $\begin{array}{c}\text { Strategi WT } \\
\text { Ciptakan strategi yang } \\
\text { meminimalkan kelemahan dan } \\
\text { menghindari ancaman }\end{array}$ \\
\hline
\end{tabular}

Sumber : Rangkuti (2015:31)

\section{HASIL DAN PEMBAHASAN}

PT. Bintang Motor adalah salah satu dealer sepeda motor Honda terbesar di Indonesia, dengan sebelas outlet di Jabodetabek, Jawa Barat, dan Sumatera. Berdiri sejak bulan September 2001. Bintang Motor berhasil mencapai penjualan unit ke 200.000 pada tanggal 9 Oktober 2010, suatu prestasi yang tidak pernah dicapai oleh dealer sepeda motor manapun di Indonesia. Penjualan 100.000 unit yang berikutnya ditargetkan tercapai sebelum tanggal 20 Desember 2012 dan target tercapai sesuai dengan keinginan.

PT. Bintang Motor akan mengembangkan jaringan dealer menjadi 18 outlet, dimana dalam waktu dekat PT. Bintang Motor akan membuka 3 cabang baru. Saat ini unit masuk servis sepeda motor PT. Bintang Motor adalah lebih dari 100,000 unit per tahun. Dalam product dan servis dealer sepeda motor Honda yaitu Penjualan (H1), Servis (H2) dan Suku cadang (H3).

\section{Strategi Pemasaran}

Dari hasil analisis SWOT diatas, maka dapat disusun tabel matriks SWOT yang terdiri dari empat strategi usaha, yaitu SO, WO, ST dan WT. Masing-masing strategi memiliki karakteristik tersendiri dan hendaknya dalam implementasi strategi dilakukan secara bersama-sama dan saling mendukung satu sama lain.

Matriks SWOT dilakukan dengan memasukkan seluruh poin Strengths, Weaknesses, Opportunities, Threats ke dalam matriks lalu membagikannya kedalam empat usaha dengan mengalokasikan hasil dari perkalian bobot dan rating kedalam strategi SO, WO, ST dan WT yang merupakan kombinasi dari semua kekuatan, kelemahan, peluang dan ancaman yang dihadapi oleh PT. Bintang Motor Kota Bengkulu.

Dari analisis matrik SWOT terdapatlah beberapa alternatif strategi. Berikut ini adalah tabel hasil analisis SWOT yang menunjukkan adanya pengaruh faktor kekuatan, kelemahan, peluang dan ancaman yang terjadi pada PT. Bintang Motor Bengkulu.

Tabel 3. Matrik SWOT

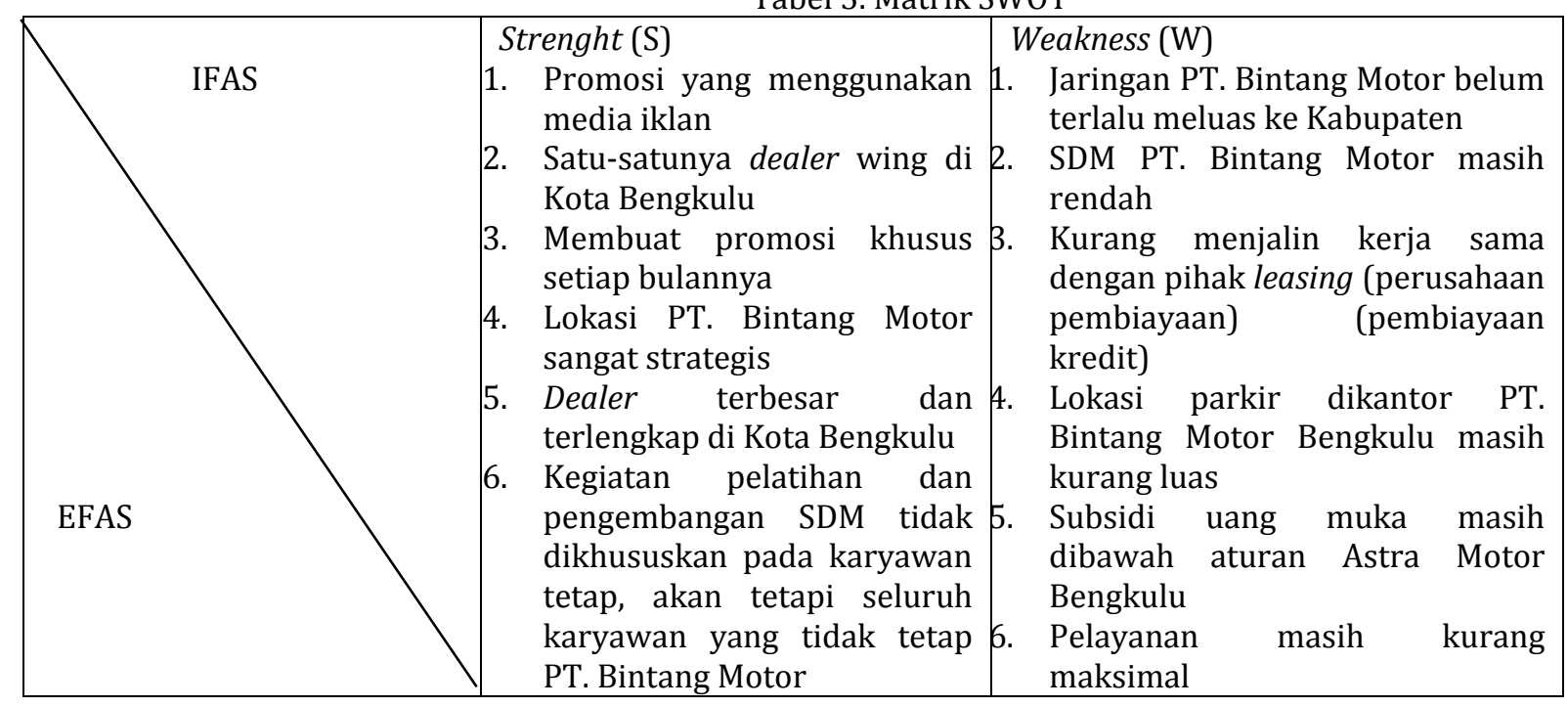


Opportunities (0)

1. Sepeda motor merupakan kendaraan pribadi yang sesuai dengan kondisi perekonomian masyarakat

2. Hubungan yang baik dengan konsumen

3. Kualitas produk Honda diakui di Masyarakat

4. Minat konsumen terhadap sepeda motor Honda terus meningkat.

5. Kemudahan dalam pembelian sepeda motor mempengaruhi minat pembeli

6. Tingkat populasi penduduk sangat besar sehingga sangat potensial dijadikan sebagai target penjual sepeda motor Honda

Threats (T)

1. Terdapat beberapa produk serupa dengan harga yang lebih murah.

2. Jumlah dealer Honda yang semakin banyak.

3. Dealer Honda lain lebih dikenal Masyarakat.

4. Perkembangan Produsen lain, seperti Yamaha sebagai salah satu pesaing terberat dalam sektor industri otomotif di Indonesia

5. Kebijakan Pemeraintah seperti kenaikan BBM sewaktu - waktu akan berpengaruh besar terhadap kelangsungan sebuah industri

6. Adanya krisis global maka daya beli pasar tentu saja akan menurun \begin{tabular}{l|l} 
Strategi (SO) & Strategi WO
\end{tabular}

Memperluas jaringan PT. Meningkatkan SDM yang Bintang Motor di daerah berpendidikan pada PT. Bintang kabupaten, untuk mempermudah konsumen dalam menerima pelayanan PT. Bintang Motor. Selain itu dengan terus meningkatkan kualitas dan mutu produk disertai dengan strategi pemanfaatan seluruh kekuatan yang ada pada PT. Bintang Motor Bengkulu seperti, mempertahankan spare part asli, luasnya bengkel, memberikan garansi dan servis gratis berkala dan selalu menjaga hubungan yang baik dan memberikan pelayanan yang baik dengan konsumen.

Motor Bengkulu, membuat dan menambah jaringan pemasaran di Kabupaten, menjalin kerja sama yang baik dengan pihak leasing (perusahaan pembiayaan) (pembiayaan kredit) agar proses penjualan lebih lancar dan semakin meningkatkan volume penjualan.

\section{Strategi ST}

Dengan menggunakan kekuatan dealer, yaitu memasarkan produk berdasarkan kualitas dan mutu melalui promosi, sponsorship dan pameran agar PT. Bintang Motor semakin diyakini dan dikenal masyarakat.

Pelayanan yang memuaskan dengan selalu memberikan keramahan kepada konsumen, program pelatihan untuk seluruh karyawan di manfaatkan dengan baik, membangun komunikasi yang baik.

\section{Strategi WT}

Langkah yang harus diambil yaitu dengan meningkatkan SDM dan meminimalkan kelemahan yang ada sesuai dengan ancaman dan mengembangkan kualitas dan mutu produk agar bisa bersaing dan dikenal oleh masyarakat.

\section{Diagram Analisis SWOT}

Dari analisis SWOT diatas maka dapat dibuat suatu ringkasan atau rekapitulasi dari perhitungan untuk melihat seberapa besar kekuatan, kelemahan, peluang dan ancaman yang ada pada PT. Bintang Motor Bengkulu. Berikut ini rekapitulasi IFAS dan EFAS.

Tabel 4. Rekapitulasi IFAS dan EFAS

\begin{tabular}{|l|l|l|l|l|}
\hline \multirow{2}{*}{ Keterangan } & \multicolumn{2}{|c|}{ IFAS } & \multicolumn{2}{c|}{ EFAS } \\
\cline { 2 - 5 } & Strenghts & Weakensses & Opportunities & Threats \\
\hline $\begin{array}{l}\text { Stragegi } \\
\text { Pemasaran }\end{array}$ & 25,71 & 13,26 & 19,3 & \\
\hline \multicolumn{2}{|c|}{ Kuadran } & \multicolumn{2}{|c|}{$25,71-13,26=12,45$} & \multicolumn{2}{c|}{$19,3-12,52=6,78$} \\
\hline
\end{tabular}

Sumber : Hasil Penelitian dan diolah, 2018 
Berdasarkan tabel diatas menjelaskan strategi pada PT. Bintang Motor Bengkulu. Hasil dari penjumlahan, maka kekuatan (strenghts) yang dimiliki oleh PT. Bintang Motor Bengkulu adalah 25,71 sedangkan kelemahan (weaknesses) 13,26 dikuadran internal factor yaitu 25,71 - 13,26=12,45 dan peluang (opportunities) yang dimiliki dari strategi tersebut sebesar 19,3 sedangkan ancaman (threats) sebesar 12,52 jadi kuadran eskternal factor yaitu 19,3 - 12,52 = 6,78 sehingga berada pada kuadran I dalam diagram analisis SWOT.

Dengan posisi tersebut, meskipun PT. Bintang Motor memiliki kekuatan tetapi juga memiliki berbagai ancaman, untuk mengatasi ancaman tersebut, PT. Bintang Motor memiliki kuadran internal dengan menerapkan strategi yaitu menggunakan kekuatan untuk memanfaatkan peluang jangka panjang dengan cara strategi difersifikasi (produk/pasar).

Berdasarkan tabel diatas maka titik temu internal factor dan eksternal factor dapat digambarkan pada diagram analisis SWOT yang akan menunjukkan pada kuadran apakah titik temu itu berada. Hal ini dapat dijadikan sebagai kombinasi antara faktor internal dan faktor eksternal PT. Bintang Motor Bengkulu. Diagram SWOT akan menunjukkan pada posisi manakah strategi pemasaran pada PT. Bintang Motor Bengkulu saat ini. Posisi strategi inilah yang akan menentukan letak kuadran strategi pemasaran PT. Bintang Motor Bengkulu. Letak kuadran tersebut akan dijadikan fundamental analisis strategi kedepannya, kuadran-kuadran dapat diamati secara jelas melalui diagram analisis SWOT berikut ini:

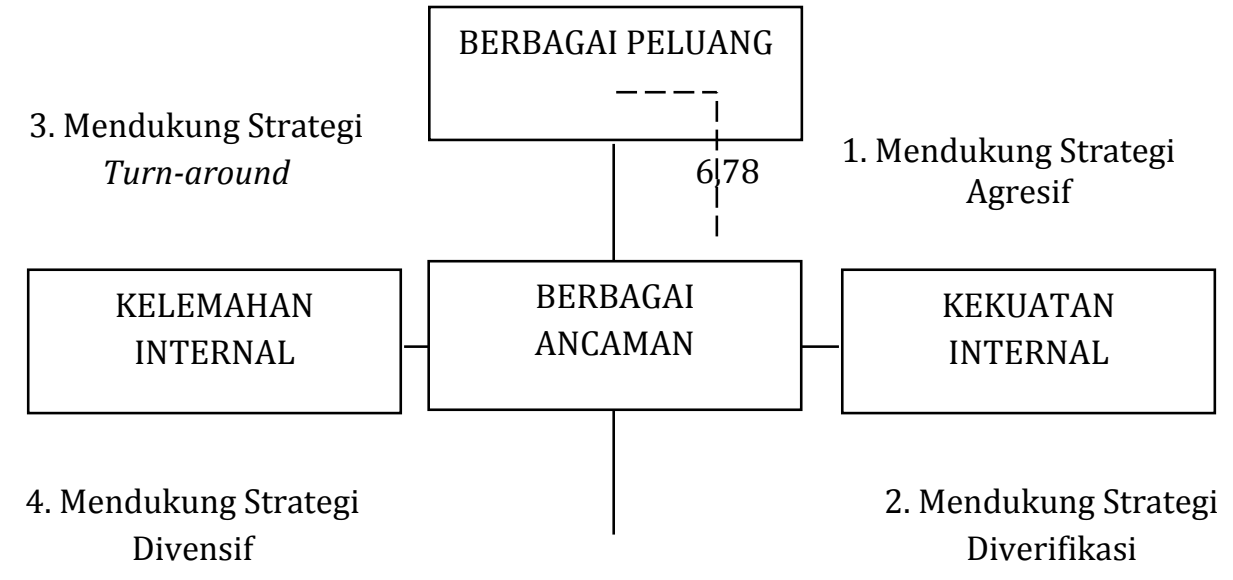

Gambar 1. Diagram Analisis SWOT

Sumber : Hasil penelitian 2018

Berdasarkan diagram diatas maka titik berada pada kuadran I, yaitu PT. Bintang Motor Bengkulu memiliki peluang dan kekuatan yang besar sehingga dapat memanfaatkan peluang yang ada. Strategi yang diterapkan dalam kondisi ini adalah mendukung kebijaksanaan yang agresif (growth oriented strategy) yaitu dengan cara:

1. PT. Bintang Motor memperluas jaringan dealer ke Kabupaten sehingga pemasaran dapat lebih optimal. Dengan memperluas jaringan dealer ini guna mempermudah konsumen untuk mendapatkan layanan penjualan PT. Bintang Motor serta memberikan kontribusi yang positif pada penjualan Honda.

2. PT. Bintang Motor Bengkulu dapat tetap menjaga kualitas dan mutu produk-produk Honda serta melakukan pelayanan yang dapat meyakini dan memuaskan konsumen.

3. Dengan menggunakan kekuatan dapat terus melakukan atau memasarkan produk berdasarkan kualitas dan mutu melalui promosi, sponsorship dan pameran agar PT. Bintang Motor agar semakin diyakini dan dikenal masyarakat serta memberikan pelayanan yang baik kepada konsumen.

Dari hasil data penelitian yang telah dianalisis sebelumnya maka dari hasil tersebut akan dibahas tentang analisis SWOT sebagai dasar perumusan strategi pemasaran di PT. Bintang Motor Bengkulu, diantaranya adalah untuk menganalisis faktor internal dan faktor eksternal untuk strategi yang tepat pada PT. Bintang Motor Bengkulu tersebut.

Untuk menganalisis faktor internal dan eksternal pada PT. Bintang Motor, maka dilakukan dengan memberikan kuesioner kepada 79 orang sampel penelitian. 4 orang dari faktor internal dan 75 orang dari faktor eksternal. Kuesioner tersebut terdiri dari 6 pertanyaan tentang kekuatan internal, 6 pertanyaan tentang kelemahan internal, 6 pertanyaan tentang peluang eksternal dan 6 pertanyaan tentang ancaman eksternal. Masing-masing pertanyaan dibagi, untuk faktor internal pertanyaan sebanyak 12 dibagikan kepada 4 responden internal yang merupakan 1 orang kepala cabang dan 3 orang bagian pemasaran PT. 
Bintang Motor Bengkulu. Untuk faktor eksternal pertanyaan sebanyak 12 dan dibagikan kepada 75 orang responden yang merupakan konsumen PT. Bintang Motor Bengkulu.

Jumlah jawaban pada setiap pertanyaan tersebut dikalkulasikan kemudian didapat bobot, bobot dicari dengan cara perkalian jumlah kalkulasi jawaban atas setiap pertanyaan dengan skala yang telah ditentukan yaitu mulai dari 1,00 untuk jawaban yang sangat penting sampai dengan 0,10 untuk jawaban yang sangat tidak penting, kemudian dibagi dengan jumlah responden.

Berdasarkan hasil analisis SWOT yang dilakukan di PT. Bintang Motor Bengkulu didapatkan total skor untuk setiap faktor kekuatan, kelemahan, peluang dan ancaman sebagai berikut:

1. Faktor Kekuatan

Total skor dari faktor internal kekuatan (strenghts) di PT. Bintang Motor Bengkulu adalah 25,71. Angka ini menunjukkan bahwa faktor kekuatan (strenghts) yang dimiliki oleh PT. Bintang Motor Bengkulu berpengaruh terhadap pemasaran dan tingkat penjualan pada PT. Bintang Motor Bengkulu.

2. Faktor Kelemahan

Total skor yang didapatkan dari faktor kelemahan (Weaknesses) di PT. Bintang Motor Bengkulu adalah 13,26. Angka ini menunjukkan bahwa faktor kelemahan yang dimiliki oleh PT. Bintang Motor Bengkulu tidak berpengaruh secara keseluruhan terhadap strategi pemasaran PT. Bintang Motor Bengkulu

3. Faktor Peluang

Total skor dari faktor peluang (Oppotunities) di PT. Bintang Motor Bengkulu terhadap strategi pemasaran adalah 19,3. Angka ini menunjukkan bahwa PT. Bintang Motor memiliki peluang yang baik dan faktor peluang yang dimiliki oleh PT. Bintang Motor Bengkulu sangat berpengaruh terhadap strategi pemasaran.

4. Faktor Ancaman

Total skor dari faktor ancaman (threats) di PT. Bintang Motor Bengkulu adalah 12,52. Angka ini menunjukkan bahwa faktor terdapat ancaman yang dimiliki oleh PT. Bintang Motor Bengkulu. Dari analisis yang dilakukan terdapat dua ancaman yang berpengaruh terhadap strategi pemasaran pada PT. Bintang Motor Bengkulu.

Dari hasil perhitungan yang telah dilakukan berdasarkan tabel diatas seperti kekuatan (strenghts), kelemahan (weaknesses), peluang (opportunities), dan ancaman (threats), maka secara keseluruhan diperoleh hasil 6 kekuatan, 2 kelemahan, 5 peluang, dan 2 ancaman. Hal ini berarti faktor ancaman dan juga kelemahan yang dimiliki oleh PT. Bintang Motor Bengkulu tersebut memang tidak berpengaruh secara keseluruhan terhadap strategi pemasaran.

Berdasarkan hasil analisis SWOT strategi memaksimalkan kekuatan merupakan gabungan dari strategi S-O (strenght-opportunity), yaitu menggunakan seluruh kekuatan yang ada dalam merebut dan memanfaatkan peluang sebesar-besarnya. Strategi ini berkaitan dengan bagaimana usaha perusahaan dalam memaksimalkan seluruh kekuatan yang dimiliki sehingga perusahaan tersebut dapat memanfaatkan peluang sekaligus menghindari ancaman yang mungkin akan terjadi dimasa yang akan datang. Adapun strategi pemasaran yang dapat dilakukan oleh PT. Bintang Motor Bengkulu yaitu memperluas jaringan dealer ke Kabupaten sehingga pemasaran dapat lebih optimal. Dengan memperluas jaringan dealer ini guna mempermudah konsumen untuk mendapatkan layanan penjualan PT. Bintang Motor serta memberikan kontribusi yang positif pada penjualan Honda.

PT. Bintang Motor Bengkulu meningkatan dan menjaga kualitas serta mutu produk-produk Honda, melakukan pelayanan yang dapat meyakinkan dan memuaskan konsumen. Dengan menggunakan kekuatan PT. Bintang Motor dapat terus melakukan atau memasarkan produk berdasarkan kualitas dan mutu melalui promosi, sponsorship dan pameran sehingga PT. Bintang Motor semakin diakui, diyakini dan dikenal oleh masyarakat.

\section{KESIMPULAN}

Berdasarkan hasil penelitian dan pengelolaan data yang telah dilakukan oleh penulis pada PT. Bintang Motor Bengkulu, maka dapat disimpulkan bahwa strategi yang sesuai bagi PT. Bintang Motor Bengkulu yaitu Strategi Agresif dan Strategi SO karena PT. Bintang Motor saat ini memiliki kekuatan (strenghts) dan peluang (opportunities) yang menguntungkan, maka strategi inilah yang dapat digunakan untuk kemajuan dan peningkatan volume penjualan PT. Bintang Motor Bengkulu. Adapun strategistrategi tersebut meliputi:

1. PT. Bintang Motor memperluas jaringan dealer ke Kabupaten sehingga pemasaran dapat lebih optimal. Dengan memperluas jaringan dealer ini guna mempermudah konsumen untuk 
mendapatkan layanan penjualan PT. Bintang Motor serta memberikan kontribusi yang positif pada penjualan Honda.

2. PT. Bintang Motor Bengkulu tetap menjaga kualitas dan mutu produk-produk Honda serta melakukan pelayanan yang dapat meyakini dan memuaskan konsumen.

3. Menggunakan kekuatan yang ada PT. Bintang Motor dapat terus melakukan atau memasarkan produk berdasarkan kualitas dan mutu melalui promosi, sponsorship dan pameran sehingga PT.

Bintang Motor semakin diyakini dan dikenal masyarakat.

\section{SARAN}

Untuk pengembangan dan peningkatan pada PT. Bintang Motor Bengkulu, maka ada beberapa hal yang disarankan yakni sebagai berikut:

1. Menerapkan hasil dari penelitian yang telah menggunakan analisis SWOT untuk diterapkan pada strategi pemasaran PT. Bintang Motor Bengkulu.

2. PT. Bintang Motor harus selalu mempertahankan kualitas dan mutu produk-produk motor Honda serta memberikan pelayanan yang baik terhadap konsumen PT. Bintang Motor Bengkulu.

3. PT. Bintang Motor harus selalu berinovasi dalam mengembangkan produk-produk motor Honda untuk siap menghadapi pesaing produsen produk lain.

\section{DAFTAR PUSTAKA}

Abdullah dan Tantri. 2012. Manajemen Pemasaran. Depok : PT. Raja Grapindo Persada

Anggrainy, Devi. 2015. Strategi Pemasaran Produk Pada Toko Devi Rotan Bengkulu. Skripsi S1 Fakultas Ekonomi, Program Studi Manajemen, Universitas Dehasen Bengkulu

Arikunto, Suharsimi. 2010. Prosedur Penelitian Suatu Pendekatan Praktik. Jakarta : Rineka Cipta

Assauri, Sofyan. 2013. Manajemen Pemasaran. Jakarta : Rajawali Press

Bilung, Septinor. 2016. Analisis SWOT Dalam Menentukan Strategi Pemasaran Sepeda Motor Honda Pada CV. Semoga Jaya Abadi Di Area Muara Wahau Kabupaten Kutai Timur. eJournal Administrasi Bisnis, 2016, 4 (1): 116-127 ISSN 2355-5408, ejournal.adbisnis.fisip-unmul.ac.id

Durianto, D. 2011. Strategi Menaklukan Pasar Melalui Riset Ekuitas dan Perilaku Merek. Jakarta : Gramedia Pustaka Utama

Fahmi, Irhan. 2011. Analisis Laporan Keuangan. Bandung : Alfabeta . Manajemen Strategis (Teori dan Aplikasi). Bandung : Alfabeta

Http://group-mitra-motor-honda.html

Iskandar. 2011. Metodologi Penelitian Pendidikan dan Sosial. Jakarta : Gaung Persada Press

Kotler, P dan Keller. 2012. Manajemen Pemasaran Jilid 1. Jakarta : Erlangga

Kotler, Philip. 2012. Prinsip-Prinsip Pemasaran Edisi 12 Jilid 1. Jakarta : Erlangga

Munadi, Fandi Ahmad. 2016. Strategi Pemasaran Untuk Meningkatkan Penjualan Kendaraan Motor pada CV Turangga Mas Motor. Skripsi S1 Fakultas Ekonomi, Jurusan Ekonomi Manajemen, Universitas Gunadarma

Mulyono. 2014. Metodologi Penelitian Kualitatif. Bandung : Remaja Rosdakarya

Purwanto, Iwan. 2011. Manajemen Strategi. Bandung : Yrama Widya

Rangkuti, Fredy. 2015. Analisis SWOT, Teknik Membedah Kasus Bisnis. Yogyakarta : Gramedia Pustaka Utama

Sugiyono. 2011. Metode Penelitian Kuantitatif Kualitatif dan R dan D, Cetakan Ke-13, Bandung: Alfabeta . 2013. Metode Penelitian Kuantitatif, Cetakan Ke-12, Bandung: Alfabeta

Sutojo dan Klein. 2010. Manajemen Strategis dan Kebijakan Perusahaan. Jakarta : PT. Damar Mulia Pustaka

Suryatama. 2014. Analisis SWOT Dalam Bisnis. Yogyakarta : Samudra Biru

Tjiptono, Andriana dan Chandra. 2012. Pemasaran Strategik. Yogyakarta : Andi

Tjiptono, Fandy. 2012. Strategi Pemasaran Edisi 4. Yogyakarta : Andi 